\title{
$4-1-2015$
}

\section{Technology and Simulation to Improve Patient Safety.}

\author{
George M. Ghobrial MD \\ Thomas Jefferson University \\ Youssef J. Hamade \\ Northwestern University Feinberg School of Medicine \\ Bernard R. Bendok \\ Northwestern University Feinberg School of Medicine \\ James Harrop \\ Thomas Jefferson University
}

\section{Follow this and additional works at: https://jdc.jefferson.edu/neurosurgeryfp \\ Part of the Surgery Commons \\ Let us know how access to this document benefits you}

\section{Recommended Citation}

Ghobrial, George M. MD; Hamade, Youssef J.; Bendok, Bernard R.; and Harrop, James, "Technology and Simulation to Improve Patient Safety." (2015). Department of Neurosurgery Faculty Papers. Paper 73.

https://jdc.jefferson.edu/neurosurgeryfp/73

This Article is brought to you for free and open access by the Jefferson Digital Commons. The Jefferson Digital Commons is a service of Thomas Jefferson University's Center for Teaching and Learning (CTL). The Commons is a showcase for Jefferson books and journals, peer-reviewed scholarly publications, unique historical collections from the University archives, and teaching tools. The Jefferson Digital Commons allows researchers and interested readers anywhere in the world to learn about and keep up to date with Jefferson scholarship. This article has been accepted for inclusion in Department of Neurosurgery Faculty Papers by an authorized administrator of the Jefferson Digital Commons. For more information, please contact: JeffersonDigitalCommons@jefferson.edu. 
Chapter 16: Technology and Simulation To Improve Patient Safety

George M. Ghobrial MD

Department of Neurological Surgery

Thomas Jefferson University Hospital

Philadelphia, PA

Youssef Hamade, MD

Department of Neurological Surgery

Northwestern University Feinberg School of Medicine

Chicago, IL

Bernard R. Bendok MD

Professor of Neurological Surgery, Radiology, and Otolaryngology

Northwestern University Feinberg School of Medicine

Chicago, IL

James S. Harrop MD

Professor of Neurological Surgery and Orthopedics

Department of Neurological Surgery

Thomas Jefferson University Hospital

Philadelphia, PA

Corresponding Author:

James S. Harrop MD

Professor of Neurological Surgery and Orthopedics

Department of Neurological Surgery

Thomas Jefferson University Hospital

Philadelphia, PA

James.harrop@jefferson.edu 


\section{Abstract/Summary:}

Improving the quality and efficiency of surgical techniques, reducing technical errors in the operating suite, and ultimately improving patient safety and outcomes through education are common goals to all surgical specialties. Present day surgical simulation programs represent an effort to enhance and optimize the training experience, to overcome the training limitations of a mandated 80 hour work week, and the overall goal of providing a well-balanced resident education in a society with a decreasing level of tolerance for medical errors. Incorporation of technical procedural based simulators is just the first step. Full integration into residency requires a scientific objective structured assessment tool and a method of independent testing and grading. One proposed method is through a video-based assessment of simulator performance. Surgical simulators represent one key attempt at maximizing the efficiency of resident education during an era of limited resources.

\section{Key Points (3-5):}

1. Neurosurgical education is increasingly looking to integrate surgical procedural based simulators as a tool for preoperative training and interim evaluation of skills.

2. Repetitive surgical training provides-helps the resident to-develop a mental rehearsal of steps. Simulation allows for that mental rehearsal to begin prior to the first operative experience. This process is particularly usefulbeneficial with infrequently encountered pathologies and procedures.

3. Using simulation as an interim evaluation tool requires a validated and reliable scoring system, which poses a unique challenge in grading technical skills.

\section{Introduction to Simulation in Neurosurgical Education}

Improving the quality and efficiency of surgical education, reducing technical errors in the operating suite, and ultimately improving patient safety and outcomes are common goals to all surgical specialties. ${ }^{1}$ Modern medical education at the turn of the $20^{\text {th }}$ century emphasized graduated levels of | responsibility through successive years of training. ${ }^{2}$ Modern day simulation measures-tools represent an effort to enhance the training experience due to the limitations of a government-mandated 80 hour work week, as well as the task of providing a well-balanced resident education in a society with a decreasing level of tolerance for medical errors. ${ }^{2,3}$

Early simulator use in medical training has been focused on the rehearsal of clinical scenarios, such as those required in advanced cardiac life support resuscitation training. ${ }^{4}$ The use of simulators has expanded rapidly after positive reports correlating technical simulator proficiency with increasing measures of technical expertise in the operating suite. ${ }^{5}$ One prospective randomized trial evaluating the use of simulation in laparoscopic inguinal hernia repair found significantly shorter operative times, 
decreased complication rates, and shorter hospital stays compared to those who had no prior simulation training. ${ }^{6}$

\section{Organized Presurgical Training Models}

In a recent survey of neurosurgery program directors, $72 \%$ felt that simulation would improve patient outcome, and that nearly half of the respondents felt that residents should reach an agreed | upon standard of simulation proficiency prior to intraoperative training. ${ }^{7}$ One formal implementations of simulator training could be in the form of annual objective assessments of resident operative skills. At the very least, since the direct effects of work hour restriction is the decrease in operative time for the resident, practice runs using a simulator would help the resident develop a mental 'script-based rehearsal' to optimize the time spent in the operating suite. ${ }^{8}$

\section{Simulation in Neurosurgery}

Simulators can be divided into physical simulators, haptic/computerized simulators, or cadaveric dissection. ${ }^{3}$ Cadaveric simulation was the first educational tool to provide anatomic education with preserved three--dimensional relationships. As a result, this modality has provided the majority of education to the present time. Improvements in computer and engineering technology haves seen the recent growth of computerized simulators. Eventually, computer graphics technology and passive three-dimensional optics became affordable for implementation in neurosimulation. Lastly, techniques of three-dimensional fabrication haves allowed for realistic physical simulators to be developed at a cost affordable for medical educationtraining institutions.

\section{Initial Use of Simulation in Neurosurgery Residency}

Surgical 'boot camps' for postgraduate first year ene-residents have been adopted and implemented in the past several years across-of a variety of surgical specialties, including cardiothoracic surgery $^{9}$, orthopedics ${ }^{10}$, otorhinolaryngology ${ }^{11}$ and neurosurgery ${ }_{=}^{12}=$ Surveys conducted in neurosurgery found a high_-level of satisfaction and knowledge retention of the skills that were emphasized at the neurosurgical boot camp. ${ }^{12}$ Appropriate simulators found at postgraduate year one training events have included central line placement, ventriculostomy catheter placement, and trauma craniotomy models.

\section{Expansion of Training Aspects Addressed by Simulators}

With the rapid growth in simulators available, interest in incorporating these into formal training has been rising. In the past year alone, results of several efforts have been published with haptic feedback devices demonstrating the various aspects of microsurgical technique that can been taught outside of the operating room, ranging from tumor handling, volumetric resection, to anatomical | accuracy_(Table 1). These technologies are ideal for techniques such as endovascular treatment of vascular pathologies, ${ }^{5}$ craniotomies, ${ }^{13,14}$ and endoscopic approaches. ${ }^{15}$ In spinal surgery, new simulations are being introduced such as the durotomy repair ${ }^{16}$, posterior cervical laminoforaminotomy ${ }_{L}{ }^{17}$, and anterior cervical discectomy models. ${ }^{18}$ These have been a welcome 
addition to prior established simulators for percutaneous pedicle screw fixation. ${ }^{19}$ Arguably these skills should be practiced prior to the entry of the operating room, asnd textbook knowledge alone is insufficient.

\section{Challenges to Designing a Formal Curriculum Using Simulation in Residency Education}

The initial introduction of simulators has already been successfully incorporated into residencies as well as national meetings such as the Congress of Neurological Surgeons. ${ }^{20}$ In an attempt to fully incorporate neurosurgical simulators into resident education, an educational curriculum and evaluation tool is needed. There are several challenges to grading surgical skills not encountered with typical testing of one's fund of knowledge. The first challenge is identifying a participant's knowledge of all skills, ${ }^{16}$ so that when repeated examination of the same participanttion over time-occurs, a frame of reference is established. The second challenge is choosing the right objective structured assessment (OSAT) to quantitatively measure a resident's interim performance. This OSAT needs to be consistent across all examiners and would have to be demonstrated in future study through validation, as well as interobserver and intraobserver reliability studies.

\section{Proposal for Validation of Neurosurgical Simulation Skills}

One proposed pathway to a more reliable and consistent grading scheme would be a videobased OSAT scoring system, rather than a traditional text-based scoring system that purely describes certain techniques on a 10-point scoring scheme. This way, the participant can videotape their examinations, following scripted instructions either independently or with a faculty instructor. This way, formal grading can be done and can be graded by an examiner. One way to validate this method would be to have multiple examiners review and grade a submitted video, using the video-based OSAT to confirm interobserver reliability. Interobserver reliability is felt to be the most important component of implementing an interim grading scheme that limits bias from having different examiners grading annual performance.

\section{The Durotomy Repair Simulator As A Model Residency Training Tool}

Unintended repair of durotomies can beare frustrating, adding significant morbidity to a spine Procedure. Dural closure of an unintended durotomy is often in a technically difficult location such as the lateral recesses of the lumbar spinal canal. Occurring at a relatively infrequent rate of $1-13 \%{ }^{21}$ leaves the resident with little case practice. Furthermore, at the time of dural repair, it would be ideal for residents to have had prior experience due to the innate difficulties of closure. In a durotomy repair $\mid$ model $_{2}{ }^{16}$, residents can practice dural closure with a variety of suture materials and sizes. While at the present stage this model does not simulate the difficulties of obscured vision by epidural bleeding or the risk of nerve root injury from suturing, it provides valuable time for the resident to practice watertight | dural closure and knot placement_(Figure 1). Residents take a multiple choicemultiple-choice pretest and undergo a didactic skills session prior to closure. Each closure is graded on timeliness, the presence | of a watertight closure, and the consistency of suturing in terms of distance between bites as well as even apposition of the edges of the durotomy. The current steps in improving the value of this tool in 
interim education is to provide a video-based OSATs where the resident can review a video of ideal techniques and emulate that in independent self-guided study and testing.

\section{Summary/Discussion:}

Modern residency education is looking forward to the number of newly developing simulators. Incorporation of these simulators is just the first step. Full integration into residency requires a scientific objective structured assessment tool and a method of independent testing and grading. One proposed method is through a video-based assessment of simulator performance. These simulators represent one key attempt at maximizing the efficiency of resident education in the era of limited duty hours.

\section{References:}

1. Harrop J. Introduction to neurosurgical simulation. Neurosurgery. Oct 2013;73 Suppl 1:8.

2. Singh H, Kalani M, Acosta-Torres S, El Ahmadieh TY, Loya J, Ganju A. History of simulation in medicine: from Resusci Annie to the Ann Myers Medical Center. Neurosurgery. Oct 2013;73 Suppl 1:9-14.

3. Gasco J, Holbrook TJ, Patel A, et al. Neurosurgery simulation in residency training: feasibility, cost, and educational benefit. Neurosurgery. Oct 2013;73 Suppl 1:39-45.

4. Perkins GD. Simulation in resuscitation training. Resuscitation. May 2007;73(2):202-211.

5. El Ahmadieh TY, Aoun SG, El Tecle NE, et al. A didactic and hands-on module enhances resident microsurgical knowledge and technical skill. Neurosurgery. Oct 2013;73 Suppl 1:51-56.

6. Zendejas B, Cook DA, Bingener J, et al. Simulation-based mastery learning improves patient outcomes in laparoscopic inguinal hernia repair: a randomized controlled trial. Annals of surgery. Sep 2011;254(3):502-509; discussion 509-511.

7. Ganju A, Aoun SG, Daou MR, et al. The role of simulation in neurosurgical education: a survey of 99 United States neurosurgery program directors. World neurosurgery. Nov 2013;80(5):e1-8.

8. Marcus H, Vakharia V, Kirkman MA, Murphy M, Nandi D. Practice makes perfect? The role of simulation-based deliberate practice and script-based mental rehearsal in the acquisition and maintenance of operative neurosurgical skills. Neurosurgery. Jan 2013;72 Suppl 1:124-130.

9. Macfie RC, Webel AD, Nesbitt JC, Fann JI, Hicks GL, Feins RH. "Boot camp" simulator training in open hilar dissection in early cardiothoracic surgical residency. The Annals of thoracic surgery. Jan 2014;97(1):161-166.

10. Sonnadara RR, Garbedian S, Safir O, et al. Orthopaedic Boot Camp II: examining the retention rates of an intensive surgical skills course. Surgery. Jun 2012;151(6):803-807.

11. Malloy KM, Malekzadeh S, Deutsch ES. Simulation-based otorhinolaryngology emergencies boot camp: Part 1: Curriculum design and airway skills. The Laryngoscope. Jul 2014;124(7):1562-1565.

12. Selden NR, Anderson VC, McCartney S, Origitano TC, Burchiel KJ, Barbaro NM. Society of Neurological Surgeons boot camp courses: knowledge retention and relevance of hands-on learning after 6 months of postgraduate year 1 training. Journal of neurosurgery. Sep 2013;119(3):796-802.

13. Lobel DA, Elder JB, Schirmer CM, Bowyer MW, Rezai AR. A novel craniotomy simulator provides a validated method to enhance education in the management of traumatic brain injury. Neurosurgery. Oct 2013;73 Suppl 1:57-65.

14. Jabbour $P$, Chalouhi N. Simulation-based neurosurgical training for the presigmoid approach with a physical model. Neurosurgery. Oct 2013;73 Suppl 1:81-84. 
15. Neubauer A, Wolfsberger S. Virtual endoscopy in neurosurgery: a review. Neurosurgery. Jan 2013;72 Suppl 1:97-106.

16. Ghobrial GM, Anderson PA, Chitale R, Campbell PG, Lobel DA, Harrop J. Simulated spinal cerebrospinal fluid leak repair: an educational model with didactic and technical components. Neurosurgery. Oct 2013;73 Suppl 1:111-115.

17. Harrop J, Rezai AR, Hoh DJ, Ghobrial GM, Sharan A. Neurosurgical training with a novel cervical spine simulator: posterior foraminotomy and laminectomy. Neurosurgery. Oct 2013;73 Suppl 1:94-99.

18. Ray WZ, Ganju A, Harrop JS, Hoh DJ. Developing an anterior cervical diskectomy and fusion simulator for neurosurgical resident training. Neurosurgery. Oct 2013;73 Suppl 1:100-106.

19. Luciano CJ, Banerjee PP, Sorenson JM, et al. Percutaneous spinal fixation simulation with virtual reality and haptics. Neurosurgery. Jan 2013;72 Suppl 1:89-96.

20. Harrop J, Lobel DA, Bendok B, Sharan A, Rezai AR. Developing a neurosurgical simulation-based educational curriculum: an overview. Neurosurgery. Oct 2013;73 Suppl 1:25-29.

21. Williams BJ, Sansur CA, Smith JS, et al. Incidence of unintended durotomy in spine surgery based on 108,478 cases. Neurosurgery. Jan 2011;68(1):117-123; discussion 123-114.

22. Patel A, Koshy N, Ortega-Barnett J, et al. Neurosurgical tactile discrimination training with haptic-based virtual reality simulation. Neurological research. Jul 2 2014:1743132814Y0000000405.

23. Hooten KG, Lister JR, Lombard G, et al. Mixed Reality Ventriculostomy Simulation: Experience in Neurosurgical Residency. Neurosurgery. Jul 182014.

24. Azarnoush H, Alzhrani G, Winkler-Schwartz A, et al. Neurosurgical virtual reality simulation metrics to assess psychomotor skills during brain tumor resection. International journal of computer assisted radiology and surgery. Jun 272014.

Table 1: Selected Simulation Efforts Using Haptic Feedback/Software in 2014.

\begin{tabular}{|c|c|c|c|c|c|}
\hline Author & Title (year) & Journal & Purpose & Design & Metric \\
\hline Patel $^{22}$ & $\begin{array}{l}\text { Neurosurgical } \\
\text { tactile } \\
\text { discrimination } \\
\text { training with } \\
\text { haptic-based } \\
\text { virtual reality } \\
\text { simulation } \\
(2014)\end{array}$ & Neurol Res & $\begin{array}{l}\text { To determine if } \\
\text { computer } \\
\text { simulation w/ } \\
\text { haptic feedback } \\
\text { devices } \\
\text { improved } \\
\text { handling with } \\
\text { surgical } \\
\text { instruments }\end{array}$ & $\begin{array}{l}\text { Group A: } \\
\text { Computer } \\
\text { training with } \\
\text { haptic stim } \\
\text { superior } \\
\text { handling } \\
\text { demonstration } \\
\text { compared to } \\
\text { Group B w/o } \\
\text { prior training. }\end{array}$ & $\begin{array}{l}\text { Ability to } \\
\text { correctly } \\
\text { identify brain } \\
\text { lesions in a } \\
\text { black box } \\
\text { using } \\
\text { instrumented } \\
\text { tactile } \\
\text { response }\end{array}$ \\
\hline Hooten $^{23}$ & $\begin{array}{l}\text { Mixed Reality } \\
\text { Ventriculostomy } \\
\text { Simulation: } \\
\text { Experience in } \\
\text { Neurosurgical } \\
\text { Residency }\end{array}$ & Neurosurgery & $\begin{array}{l}\text { To assess if } \\
\text { simulation can } \\
\text { improve } \\
\text { ventriculostomy } \\
\text { placement }\end{array}$ & $\begin{array}{l}\text { Physical } \\
\text { simulator } \\
\text { measuring } \\
\text { accuracy }\end{array}$ & $\begin{array}{l}\text { Comparison } \\
\text { to controls, } \\
\text { distance to } \\
\text { Foramen of } \\
\text { Munro }\end{array}$ \\
\hline
\end{tabular}




\begin{tabular}{|l|l|l|l|l|l|}
\hline Azarnoush $^{24}$ & $(2014)$ & & & & \\
& $\begin{array}{l}\text { Neurosurgical } \\
\text { virtual reality } \\
\text { simulation } \\
\text { metrics to } \\
\text { assess } \\
\text { psychomotor } \\
\text { Skills during } \\
\text { brain tumor } \\
\text { resection } \\
\text { (2014) }\end{array}$ & $\begin{array}{l}\text { Int J } \\
\text { Comput } \\
\text { Assist } \\
\text { Radiol } \\
\text { Surg }\end{array}$ & $\begin{array}{l}\text { Software/Haptic } \\
\text { feedback To } \\
\text { develop tumor } \\
\text { handling }\end{array}$ & $\begin{array}{l}\text { Use of } \\
\text { NeuroTouch } \\
\text { Software. }\end{array}$ & $\begin{array}{l}\text { Tier 1 metric: } \\
\text { Volumentric } \\
\text { resection_\%), } \\
\text { normal brain } \\
\text { resected_(\%), } \\
\text { Tier 2 tip } \\
\text { path, OR time, } \\
\text { pedal } \\
\text { activation, } \\
\text { Tier 3, sum of } \\
\text { applied forces } \\
\text { (estimating } \\
\text { force of } \\
\text { manipulation) }\end{array}$ \\
\hline
\end{tabular}

Figures

Figure 1. Lumbar Durotomy Repair Model. A Sawbones ${ }^{\mathrm{TM}}$ model of the lumbar spine is seen with the spinal canal filled with a latex tube distended by a set hydrostatic pressure. Residents are instructed to make a set durotomy $(1 \mathrm{~cm})$ and are evaluated by their technique and timeliness under instruction.

These simulators are simple that they can be used in a self-directed manner. 